\title{
Realisasi Fungsi Keluarga Dalam Pendidikan Anak Menurut Mahasiswa IAIN Salatiga Tahun 2016
}

\author{
Bahroni \\ Institut Agama Islam Negeri Salatiga \\ babronistainsala3@gmail.com
}

\begin{abstract}
This study aims to describe in general the realization of family functions, and the realization of family functions in perspective Q.S. Luqman: 13 s.d. 19 in children's education. The data were collected using questionnaires and interviews to a number of IAIN Salatiga students, and library techniques, data retrieval techniques from various written sources in the context of child education that support data analysis. The results of this study showed that realization of family function in general and in perspective Q.S. Luqman: 13 s.d. 19 in childhood education has been going pretty well, as far as the internal affairs of the student families who are responding in this study. But, when it comes to surrounding communities outside the student family, not all families are fully functioning properly.
\end{abstract}

Keywords: Family Functions, Children's Education

\begin{abstract}
Abstrak
Penelitian ini bertujuan untuk mendeskripsikan realisasi fungsi keluarga secara umum, dan realisasi fungsi keluarga dalam perspektif Q.S. Luqman: 13 s.d. 19 dalam pendidikan anak. Pengumpulan data dilakukan melalui angket dan wawancara kepada sejumlah mahasiswa IAIN Salatiga, serta teknikpustaka, yakni teknik pengambilan data dari berbagai sumber tertulis dalam konteks pendidikan anak yang mendukung analisis data. Hasil penelitian ini menunjukkan babwa realisasi fungsi keluarga secara umum maupun dalam perspektif Q.S. Luqman: 13 s.d. 19 dalam pendidikan anak telah berlangsung dengan cukup baik, sejaub yang terkait dengan internal keluarga mahasiswa yang menjadi responden dalam penelitian ini. Namun, ketika menyangkut masyarakat sekitar di har keluarga mahasiswa, masib belum semua keluarga merealisasikan fungsinya dengan baik.
\end{abstract}

Kata Kunci: Fungsi Keluarga, Pendidikan Anak.

Permalink/DOI:http://dx.doi.org/10.18326/infsl3.v11i1.247-268 


\section{Pendahuluan}

Ibarat orang bertani, keluarga merupakan sepetak lahan persemaian yang semestinya telah dipersiapkan sedemikian rupa sehingga siap untuk ditaburi benih-benih tanaman. Agar menghasilkan "tunastunas muda" yang berkualitas dan siap ditangkarkan pada lahanlahan pertanian yang lebih luas, tentu saja dibutuhkan tempat persemaian yang tanahnya subur, cukup air, cukup cahaya matahari, dan lingkungan yang aman dari serangan penyakit maupun hama tanaman. Demikianlah, keluarga merupakan tempat menyemai atau mempersiapkan generasi muda yang akan meneruskan perjuangan dari para pendahulunya.

Jika keluarga sebagai tempat persemaian itu sangat kondusif, tentu saja akan menghasilkan generasi penerus yang tangguh dan tanggap sehingga lebih siap menghadapi berbagai tantangan dalam medan juang kehidupan di masyarakat luas. Sebaliknya, sebuah keluarga yang tidak kondusif untuk mempersiapkan generasi penerus, bukan saja tidak menghasilkan tunas-tunas muda yang berkualitas, tetapi justru menghasilkan generasi yang sarat dengan masalah, generasi yang selalu membuat masalah, generasi yang bermasalah, sehingga untuk mengatasinya memerlukan waktu, perhatian, dan energi yang tidak sedikit.

Ibarat angka, generasi yang bermasalah yang dihasilkan dari keluarga yang tidak kondusif itu adalah angka minus. Agar menjadi angka plus, tentu memerlukan perhatian dan perlakuan yang serius karena sebelum menjadi plus harus melewati angka nol dulu. Pendek kata, perubahan dari generasi minus menuju plus itu menyita perhatian dan waktu tersendiri yang semestinya perhatian dan waktu itu sudah dapat dipergunakan untuk "menangkarkan tunas-tunas muda yang berkualitas pada lahan yang lebih luas" sehingga "panen raya" akan segera menjadi kenyataan.

Demikianlah gambaran betapa pentingnya menciptakan kondisi keluarga yang harmonis, keluarga yang tenteram yang penuh dengan cinta dan kasih sayang (sakinah, mawaddah, wa rahmah) sehingga kondusif untuk mendidik anak-anak terutama dalam menanamkan akhlak mulia kepada mereka, dimana akhlak mulia ini merupakan prasyarat yang harus ada bagi tercapainya cita-cita: keluarga bahagia. 
Keluarga bahagia adalah dambaan setiap orang, anak yang shalih adalah dambaan setiap orang tua. Pada dasarnya anak lahir dalam keadaan suci. Kecenderungannya kepada yang baik maupun yang tidak baik adalah karena lingkungannya terutama ayah, ibu, dan orang-orang terdekatnya. Orang tua adalah pendidik pertama dan utama. Mereka berdua yang bertanggung jawab penuh atas kemajuan perkembangan anak kandungnya, karena sukses tidaknya anak sangat tergantung pengasuhan, perhatian, dan pendidikannya. Kesuksesan anak kandung merupakan cermin kesuksesan orang tua juga.

Berdasarkan pemikiran tersebut, penelitian yang berjudul Realisasi Fungsi Keluarga dalam Pendidikan Anak Menurut Mahasiswa IAIN Salatiga Tahun 2016 adalah sangat penting dilaksanakan yang bertujuan untuk mendeskripsikan realisasi fungsi keluarga secara umum dan realisasi fungsi keluarga dalam perspektif Al-Quran surat Luqman ayat 13 s.d. 19 dalam pendidikan anak menurut mahasiswa IAIN Salatiga.

\section{Pengertian Pendidikan}

Secara singkat, pendidikan diartikan sebagai suatu proses untuk memanusiakan manusia. Artinya, seorang bayi yang lahir tidak dengan sendidrinya akan menjadi manusia (yang berbudaya). Untuk menjadikanmanusiayang berbudaya haruslahmelalui pengembangan dan pembinaan jasmani dan ruhani melalui aktivitas pendidikan. Indar (1994:16) menyatakan bahwa pendidikan merupakan usaha manusia untuk menumbuhkan dan mengembangkan potensi-potensi pembawaan baik jasmani maupun ruhani sesuai dengan nilai-nilai yang ada dalam masyarakat dan kebudayaan. Tilaar (2000:28-31) mengemukakan bahwa pendidikan pada hakikatnya merupakan suatu proses menumbuhkembangkan eksistensi peserta-didik yang memasyarakat, membudaya, dalam tata kehidupan yang berdimensi lokal, nasional, dan global. Rumusan operasional mengenai hakikat pendidikan tersebut memiliki komponen-komponen sebagai berikut. 
Pertama, pendidikan merupakan suatu proses berkesinambungan. Artinya, peserta-didik memiliki kemampuankemampuan yang immanen sebagai makhluk yang hidup dalam suatu masyarakat. Kemampuan-kemampuan tersebut berupa dorongan-dorongan, keinginan, dan elan vital, yang ada pada manusia. Kemampuan-kemampuan tersebut harus dikembangkan dan diarahkan sesuai dengan nialai-nilai yang hidup atau dihidupkan dalam masyarakat. Selanjutnya proses tersebut merupakan suatu proses yang berkesinambungan, yang terus-menerus dalam arti adanya interaksi dengan lingkungannya. Pendidikan tidak berhenti ketika peserta-didik menjadi dewasa tetapi akan terus-menerus berkembang selama terdapat interaksi antara manusia dengan lingkungan sesama manusia serta lingkungan alamnya.

Kedua, proses pendidikan berarti menumbuhkembangkan eksistensi manusia. Artinya, eksistensi atau keberadaan manusia adalah suatu keberadaan interaktif. Interaksi ini bukan hanya interaksi dengan sesama manusia melainkan juga dengan alam dan dunia ide termasuk dengan Tuhannya. Eksistensi manusia tidak pernah selesai dan terus-menerus terjadi sepanjang hayatnya. Dorongan, keinginan, dan elan vital hanyalah komponen-komponen dalam menumbuhkembangkan eksistensi manusia. Eksistensi manusia selalu berarti dengan hubungan sesama manusia baik yang dekat maupun dalam ruang lingkup yang lebih luas. Tanggung jawab manusia yang ditumbuhkembangkan melalui proses pendidikan bukan hanya berdimensi lokal melainkan juga berdimensi nasional dan global.

Ketiga, eksistensi manusia yang memasyarakat. Proses pendidikan adalah proses mewujudkan eksistensi manusia yang memasyarakat. Hal ini berarti bahwa tujuan pendidikan itu tidak terlepas dari pendidikan yang berada dalam konteks kehidupan masyarakat. Pendidikan adalah produk suatu masyarakat tertentu. Dengan demikian, tujuan pendidikan bukanlah merupakan suatu masalah yang dipisahkan dari masyarakat yang memilikinya, melainkan kongruen dengan visi masyarakat setempat.

Keempat, proses pendidikan dalam masyarakat yang membudaya. Inti dari kehidupan bermasyarakat adalah nilai- 
nilai. Nilai-nilai tersebut perlu dipahami, dihayati, diamalkan, dan dilestarikan oleh seluruh anggota masyarakatnya. Keseluruhan proses tersebut adalah kebudayaan. Dengan demikian, tidak mungkin suatu masyarakat tanpa budaya. Masyarakat bukan hanya memiliki budaya melainkan juga membudaya, dalam arti selain nilainilai yang ada dilestarikan juga akan muncul nilai-nilai baru. Oleh karena itu, proses pendidikan dalam suatu masyarakat yang berpola kepada kebudayaannya, haruslah mengarah kepada penghayatan dan pelaksanaan nilai-nilai yang hidup, keraturan, dan kedisiplinan para warganya.

Berdasarkan uraian tersebut, pengertian pendidikan akan selalu berkaitan dengan bahasan hal-hal sebagai berikut. Pertama, pendidikan mengandung tujuan yang ingin dicapai, yaitu aktualisasi potensi-potensi manusia agar bermanfaat bagi kepentingan hidupnya baik sebagai individu maupun sebagai warga masyarakat. Kedua, untuk mencapai tujuan tersebut, pendidikan perlu melakukan usaha yang disengaja dan diprogramkan untuk memilih filsafat atau ideologi kehidupan tertentu sebagai dasar pijakan, materi pembelajaran, strategi kegiatan, dan teknik penilaian yang sesuai. Ketiga, kegiatan pendidikan dapat diberikan di lingkungan keluarga, sekolah, dan masyarakat berupa pendidikan jalur sekolah (formal), dan pendidikan jalur luar sekolah (informal dan nonformal).

Perspektif yang agak berbeda mengenai pengertian pendidikan disampaikan oleh Muhadjir (1993) dengan paparannya mengenai unsur dasar dan komponen pokok pendidikan. Menurutnya, unsur dasar pendidikan terdiri atas. Pertama, pihak yang memberi. Kedua, pihak yang menerima. Ketiga, 'tujuan baik" dari yang memberi bagi bagi perkembangan atau kepentingan yang menerima. Tujuan baik ini merupakan: (1) Tujuan yang berfungsi sebagai alat untuk mencapai tujuan lain. John Dewey menyebutnya sebagai means (alat/cara) untuk mencapai ends (tujuan-tujuan), yang pada proses berikutnya ends tersebut menjadi means untuk mencapai ends baru. (2) Tujuan yang berada dalam subjek, yaitu berupa perkembangan atau pertumbuhan subjek. (3) Tujuan yang merupakan sesuatu yang ideal dan berada di luar subjek, yaitu berupa nilai-nilai hidup (values of life). Pendidikan sering disebut ilmu normatif: tidak ingin sekedar mendeskripsikan/menjelaskan, 
tetapi ingin memberitahukan perlu dan harusnya mencapai sesuatu cita ideal atau mencapai sesuatu yang dilihat atau diuji dari nilai hidup memang baik. Keempat, cara/jalan yang baik. Tujuan baik dengan cara/jalan yang tidak baik bukanlah aktivitas pendidikan. Semboyan the end justifies the means (tujuan menghalalkan segala cara) bukanlah semboyan yang bersemangatkan pendidikan. Siapa yang salah dalam menempuh cara, maka ia akan sesat dan tidak akan sampai ke tujuan (yang hakiki). Kelima, konteks yang positif. Konteks adalah situasi/keadaan yang melingkupi sebuah aktivitas. Suatu konteks dapat berperan positif dan negatif. Upaya pendidikan perlu secara aktif menyisihkan yang negatif atau mengubahnya menjadi positif. Berdasarkan lima unsur dasar tersebut, pendidikan dapat dirumuskan sebagai "aktivitas interaktif antara pendidik dan subjek-didik untuk mencapai tujuan baik dengan cara yang baik dalam konteks positif."

Selanjutnya, komponen pokok pendidikan terdiri atas halhal sebagai berikut. Pertama, program/kurikulum.Dalam aktivitas penedidikan, kurikulum merupakan merupakan penjabaran dari idealisme, cita-cita, tuntutan masyarakat, atau kebutuhan tertentu. Arah, alternatif, fungsi, dan hasil pendidikan sangat bergantung pada kurikulum. Kedua, subjek-didik.Aktivitas subjek-didik bukan sekedar pasif-reseptif-reaktrif, melainkan aktif-kreatif-responsif. Bagaimanapun baiknya kurikulum, bila subjeknya pasif-reseptif saja, hasilnya adalah warga yang tidak dinamis (statis). Ketiga, personifikasi pendidik, yaitu mempribadinya keseluruhan yang diajarkannya, bukan hanya isinya, melainkan juga nilainya.Sosok guru yang dapat "digugu lan ditiru", bukan "wagu tur saru". Keempat, konteks belajar.Mempribadikan informasi dan tampilan pendidik menumbuhkan konteks sosial menjadi konteks belajar. Berdasarkan lima unsur dasar dan empat komponen pokok tersebut, pendidikan dapat dirumuskan sebagai "upaya terprogram dari pendidik-mempribadi untuk membantu subjek-didik agar berkembang ke tingkat yang normatif lebih baik dengan cara yang normatif juga baik.” 


\section{Fungsi dan Tujuan Pendidikan}

Dalam kehidupan manusia secara umum, pendidikan memiliki fungsi sebagai suatu kekuatan yang menentukan prestasi dan produktivitas di bidang yang lain. Sebagai suatu kekuatan, berarti pendidikan memiliki pengaruh yang sangat signifikan bagi kehidupan manusia untuk menentukan satu dunia yang seperti apa yang ingin dicapai dan bagaiamana cara mencapainya. Tidak ada satu fungsi dan jabatan dalam masyarakat tanpa melalui proses pendidikan. Dengan kata lain, seluruh aspek kehidupan memerlukan proses pendidikan, baik berupa pendidikan formal, informal, ataupun nonformal. Terkait dengan hal tersebut, Richey (1968:489) mengemukakan bahwa istilah pendidikan berkenaan dengan fungsi yang luas dari pemeliharaan dan perbaikan kehidupan suatu masyarakat. Pendidikan adalah suatu aktivitas sosial yang memungkinkan masyarakat tetap ada dan berkembang.

Ditinjau dari segi antropologi kultural dan sosiologi, fungsi pendidikan menurut Muhadjir (1993: 10-14) adalah sebagai berikut. Pertama, untuk menumbuhkan kreatifitas subjek-didik. Kreasilah yang menjadikan masyarakat lebih maju dan lebih berkembang. Di era teknologi informasi yang canggih dewasa ini, informasi yang diterima manusia sangat beragam, ada yang bermanfaat dan ada pula sampah informasi yang beracun. Keragaman informasi menantang manusia untuk memilah, memilih atau menyaring validitas (kebenaran) isinya, terpercaya salurannya, dan sebagainya. Dalam menyaring informasi tersebut dibutuhkan kemampuan kreatif untuk menggeneralisasikan, mengabstrakkan, menemukan hubungan unuiknya untuk akhirnya menampilkan pendapat, sikap, dan wawasan yang tepat, sehingga kita tidak hanyut bahkan tenggelam dalam sampah informasi. Kedua, untuk menjaga kelestarian nilainilai Ilahi/insani. Masyarakat manusia dapat berlangsung terus karena adanya kemauan untuk menaati atau mengamalkan nilainilai Ilahi/insani, seperti ketakwaan, kejujuran, kasih sayang, kedisiplinan, tolong menolong, keadilan, kesantunan, kesabaran, tanggung jawab, saling percaya, kesetiaan, dan sebagainya. Ketiga, untuk menyiapkan tenaga kerja produktif. Dalam hal ini, harus ditekankan bahwa pengertian tenaga kerja produktif itu tidak hanya dalam arti ekonomi saja, tetapi juga dalam arti keberagamaan, 
sosial, dan kultural. Juga, bukan dalam arti menyesuaikan kepada prediksi kebutuhan ekonomi, melainkan dalam arti mengantisipasi masa depan, sehingga pendidikan memberi corak struktur kerja masa depan.

\section{Keluarga yang Kondusif bagi Pendidikan Anak}

Suatu keluarga diawali dari sepasang suami isteri, kemudian lahir anak-anak mereka.Itulah keluarga inti tempat berinteraksi yang pertama kali bagi setiap anak. Dalam keluarga itulah berkembangnya indidvidu dan tahap-tahap awal proses pembentukan kepribadian anak melalui internalisasi nilai-nilai yang terpantul dari emosi, minat, sikap, dan perilaku orang tuanya. Ketenangan, kedamaian, dan keharmonisan keluarga sangat menentukan terciptanya situasi yang kondusif bagi pendidikan anak-anak. Begitu pentingnya keluarga sebagai pusat pendidikan yang meletakkan dasar-dasar pembentukan kepribadian anak, maka Islam memberikan pedoman mengenai keluarga yang kondusif bagi pendidikan, sebagai berikut. Pertama, tujuan berumah tangga adalah untuk mendapatkan ketenangan, ketenteraman, dan kedamaian dengan dilandasi saling cinta dan kasih sayang (Q.S. Ar-Rum: 21), dan diniati atau dengan komitmen untuk beribadah kepada Allah. Kedua, memilih pasangan ideal dengan mengutamakan persyaratan akhlak dan agamanya. Ketiga, anggota keluarga harus menyadari dan memenuhi hak dan tanggung jawab masing-masing.

Selanjutnya, fungsi keluarga bagi anak secara umum adalah (1) tempat mendapatkan sesuatu yang berguna untuk mempertahankan kehidupannya, pencegahan bahaya dari luar, latihan bekerjasama untuk persiapan bermasyarakat, (2) tempat mengadakan ikatanikatan psikologik dengan seluruh anggota keluarga, (3) tempat memperoleh kesempatan untuk membentuk identitas personal yang terikat dengan identitas keluarga, (4) tempat mempelajari pola-pola peran individu yang sesuai dengan peran jenis kelaminnya, (5) tempat belajar berintegrasi dengan masyarakat dan menerima polapola kehidupan masyarakat, (6) tempat belajar untuk menghargai kreativitas dan inisiatif dari individu lain, serta (7) tempat berekreasi dan curhat. 
Adapun fungsi keluarga dalam pendidikan menurut Q.S. Luqman (31): 13-19 adalah untuk memberi landasan pembentukan kepribadian anak, yaitu untuk (1) menanamkan iman dan tauhid, (2) menumbuhkan sikap hormat dan bakti pada orang tua, (3) menumbuhkan semangat kerja dengan penuh kejujuran, (4) mendorong anak taat beribadah, terutama salat, (5) menanamkan cinta kebenaran (ma'ruf) dan menjauhi yang buruk (munkar), (6) menanamkan jiwa sabar dalah menghadapi cobaan, (7) menumbuhkan sikap rendah hati, tidak angkuh dan sombong dalam pergaulan, serta (8) menanamkan sikap hidup sederhana.

\section{Metode Penelitian}

Penelitian ini menggunakan pendekatan kualitatif-deskriptif, yakni bertujuan untuk mengungkapkan berbagai informasi kualitatif dengan pendeskripsian yang teliti dan penuh nuansa untuk menggambarkan secara cermat sifat-sifat suatu hal, keadaan, fenomena, dan tidak terbatas pada pengumpulan data, tetapi meliputi analisis dan interpretasi data tersebut (Sutopo, 2002:111).

Sumber data dalam penelitian berupa pernyataan atau jawaban dari sejumlah mahasiswa IAIN Salatiga. Adapun pengumpulan datanya menggunakan teknik angket, wawancara, dan pustaka. Untuk menjamin keabsahan dan kredibilitas data penelitian, digunakan teknik trianggulasi,yang lazim dipakai dalam penelitian kualitatif.

Teknik pengolahan dan analisis data dilakukan langkahlangkah sebagai berikut: (1) pengurutan data sesuai dengan masalah yang akan dijawab; (2) pembentukan satuan-satuan data dalam stiap urutannya sesuai dengan kemungkinan hubungan cici kategorinya; (3) interpretasi nilai data sesuai dengan masalah yan akan dijawab; (4) evaluasi tingkat kelayaan dan kelengkapan data dikaitkan dengan rentang masalahnya. Evaluasi ini juga menyangkut penafsiran validitas data bila dihubungkan dengan isi penjelasan yang diberikan. Berdasarkan hasil evaluasi ini dapat ditentukan perlu tidaknya mencari data baru. Berdasarkan hasil analisis, selanjutnya dilakukan pendeskripsian, yakni penjelasan secara sistematis 
tentang fakta tertentu yang dihasilkan berdasarkan konsep dan cara kerja yang telah ditetapkan (Aminuddin, 1995:67).

\section{Analisis}

Realisasi fungsi keluarga dalam pendidikan anak secara umum dapat dideskripsikan sebagai berikut. Pertama, tempat mendapatkan sesuatu yang berguna untuk mempertahankan kehidupannya, pencegahan bahaya dari luar, latihan bekerjasama untuk persiapan bermasyarakat. Di dalam sebuah keluarga seseorang akan mendapatkan perlindungan yang tidak akan pernah didapatkan dari manapun ia berada, dalam keluarga pun kedua orang tua atau saudara pun akan mengajarkan tentang agama, budaya dan cara bagaimana seseorang berinteraksi ke masyarakat (Uswatun Khasanah).

Realisasi dari fungsi ini juga sudah cukup baik, sebagaimana dinyatakan oleh Yunita Sari, bahwa dengan hal-hal sederhana yang dapat menjelaskannya seperti sebuah rumah yang menjadi tempat pulang ke anggota keluarga.Masyarakat di lingkungannya selalu menganggap rumah dan anggota keluarga yang lengkap sudah sangat lebih dari rasa aman, rasa kebersamaan dapat mencegah dari bahaya dari luar. Senada dengan Yunita Sari, Ninda Septa Zulfanita menyatakan bahwa fungsi itu sudah terealisasi didalam keluarganya, mereka mencari nafkah untuk memenuhi kebutuhan seperti makan, sekolah, dan kebutuhan pokok lainnya. Selain itu, mereka juga memberikan kasih sayang dan perhatian yang terus menerus, serta dari segi keagamaan dan pendidikan juga sudah diberikan sejak dia masih kecil. Sedangankan mengenai pencegahan bahaya dari luar mereka juga mengajarkan tentang etika sopan santun, larangan merokok, larangan keluar malam yang tidak bermanfaat dan tentunya membatasi pergaulan yang sekiranya akan berdampak negatif. Dia dan adiknya juga mengikuti kegiatan remaja di desanya seperti: kerja bakti dan yasinan remaja.

Kedua, mengadakan ikatan-ikatan psikologik dengan seluruh anggota keluarga. Menurut Muhammad Lutfil Khakim, hubungan antar anggota keluarga harus selalu dijaga keharmonisannya, orang 
tua harus membimbing anaknya dengan baik, anak harus patuh dan hormat kepada orang tua. Dalam keluarga Maulida Swastuti, realisasi fungsi pada poin kedua juga terlasana dengan baik, ia menyatakan bahwa ikatan-ikatan psikologik dengan seluruh anggota keluarga dalam keluarganya sudah terlaksana dengan baik. Sebagai contoh, ia dan kedua kakaknya diajari untuk memiliki kepekaan perasaan. Sehingga saat anggota keluarga tertenu mengalami masalah misalnya, anggota keluarga yang lain turut merasakan dan membantu mencari pemecahan atau solusi dari masalah yang dihadapi. Terkait dengan hal tersebut, Fuji Astuti menyatakan bahwa yang dimaksud mengadakan ikatan-ikatan psikologik menurutnya adalah menjalin hubungan yang dilandasi saling cinta dan kasih sayang antar anggota keluarga. Orang tuanya selalu memberikan kasih sayang dan perhatian yang luar biasa yang tidak bisa dia dapatkan dimanapun. Mereka berusaha memberikan yang terbaik untuknya meskipun dia terkadang tidak menuruti kemauannya dan mereka rela untuk melakukan apapun untuk kebahagiaan anaknya. Kemudian mereka juga mengajari anak-anaknya untuk saling tolongmenolong, di saat salah satu anggota keluarga dalam kesusahan, mereka harus menolong dan memberikan motivasi untuknya.

Ketiga, kesempatan untuk membentuk identitas personal yang terkait dengan identitas keluarga. Terkait dengan fungsi ketiga ini, Yunita Sari menyatakan bahwa identitas personal yang terwujud dari masyarakat sekitar adalah sebuah identitas yang didapatkan secara langsung dari keluarga yang terdahulu. Secara tidak langsung setiap anak yang tumbuh di lingkungan terdekat mendapatkan identitas yang menunjukan 'status' mereka. Namun yang terjadi saat ini kebanyakan seiring tumbuhnya anak tersebut kemudian dia mendapatkan identitas yang berbeda, hal ini terjadi dikarenakan faktor-faktor eksternal. Realisasi dari fungsi ketiga ini cukup baik sebagaimana dinyatakan oleh Ninda Septa Zulfanita, bahwa fungsi ini sudah diterapkan dalam keluarganya, ia diperbolehkan menjadi seseorang yang ia inginkan, seperti cita-citanya menjadi guru, kedua orangtunya tidak melarangnya tetapi justru memberi kebebasan untuk mewujudkan cita-cita tersebut, kedua nenek dan tantenya juga seorang guru, itu yang memotivasinya agar menjadi seperti mereka. 
Keempat, mempelajari pola-pola peran individu yang sesuai dengan peran jenis kelaminnya. Septi Purwatiningsih menyatakan bahwa laki-laki dan perempuan memiliki peranan yang berbeda, sehingga setiap anak akan mengetahui peranan mereka yang tepat dari keluarganya. Keluarga wajib memberikan pendidikan mengenai hal ini. Misalnya saja, ayah adalah seorang laki-laki, sehingga peranan utamanya dalam keluarga adalah menjadi kepala keluarga dan mencari nafkah. Dan ibu adalah seorang wanita, maka salah satu perannya dalam keluarga adalah menjaga dan mendidik anak-anaknya. Keluarga wajib memberi tahu kepada anak-anaknya mengenai apa saja yang harus dan boleh dilakukan, serta apa saja yang tidak boleh dilakukan.

Terkait dengan hal tersebut, Viqi Khoerulmuna Sanjaya menyatakan bahwa sebagai seorang laki-laki dia dididik untuk memiliki rasa tanggung jawab yang besar, berperilaku baik dan benar. Karena kelak dia akan menjadi seorang ayah dan imam untuk istri dan juga anak-anaknya. Kakaknya juga dididik untuk menjadi istri yang baik dan sholihah, patuh kepada suami, dan menjadi ibu yang baik bagi anak-anaknya nanti. Tentu kedua orang tuanya mengajar dan mendidiknya dengan berpedoman kepada agama Islam. Selain itu, dia juga mencontoh kedua orangtuanya bagaimana mereka mendidik anaknya, mencari nafkah, dan juga menjadi teladan bagi mereka. Oleh karena itu, kedua orangtuanya selalu berpesan agar menanamkan atau mengajarkan ilmu keagamaan sejak kecil supaya mereka tahu mana yang mana yang benar dan mana yang salah.

Kelima, belajar berintegrasi dengan masyarakat dan menerima pola-pola kehidupan masyarakat. Terkait dengan fungsi ini, Dwi Wulandari menyatakan bahwa integrasi sosial adalah proses penyesuaian unsur-unsur yang berbeda dalam masyarakat sehingga menjadi satu kesatuan. Unsur-unsur yang berbeda tersebut dapat meliputi ras, etnis, agama, bahasa, kebiasaan, dan sistem nilai.Integrasi sosial ini diperlukan agar masyarakat tidak bubar meskipun menghadapi berbagai tantangan, baik berupatantangan fisik maupun konflik yang terjadi dalam konteks sosial budaya seiring dengan perkembangan pola pikir masyarakat. 
Sementara itu, Pangesti Ardianti menyatakan bahwa dengan belajar berintegrasi dengan masyarakat dan menerima pola-pola kehidupan masyarakat ini akan membentuk anak lebih peduli dengan apa yang ada dilingkungannya, dia akan mengetahui tentang masalah-masalah yang ada dilingkungan masyarakat dan lebih peka dalam memecahkan masalah dengan bermusyawarah.

Dalam keluarga Maulida Swastuti, fungsi kelima ini dapat terealisasi dengan baik. Hal ini tercermin dari pernyataannya bahwa ayah dan ibunya telah mengajarinyauntuk bersosialisasi dengan masyarakat sejak dia masih kanak-kanak. Hal tersebut membuatnya mempelajari dan menerima perbedaan-perbedaan yang ada di masyarakat.

Berbeda dengan keluarga atau masyarakat di lingkungan Anisha dan Maulida, di lingkungan masyarakat Maharani Silvia Malikhah, fungsi kelima ini belum begitu dilaksanakan dengan baik. Dalam hal ini dia menyatakan bahwa masih ada beberapa yang menutup diri dari masyarakat bahkan mereka tidak mengenal tetangganya walaupun orang tuanya tidak menutup diri. Menurutnya, hal ini disebabkan kurangnya dorongan orang tua untuk mengajak anak-anaknya berinteraksi dengan tetangga sekitar.

Keenam, belajar untuk menghargai kreativitas dan inisiatif dari individu lain. Istighfarin Speleony Triningsih menyatakan bahwa Islam sangat menganjurkan umatnya untuk berkarya untuk keselamatan umat sesuai dengan bidangnya masing-masing. Untuk itu, perlu dikembangkan sikap menghargai karya orang lain agar terciptanya kompetisi dalam berkarya untuk keselamatan umat (manusia). Setiap manusia yang terlahir di dunia dikaruniai berbagai macam potensi, salah satu potensi yang dikaruniakan kepada manusia adalah potensi berkarya, maka dari itu pembentukan sikap menghargai kreativitas orang lain perlun diajarkan oleh orang tua agar anak tidak bersikap angkuh kepada orang lain.

Realisasi fungsi keenam ini pada beberapa keluarga mahasiswa dapat berlangsung dengan cukup baik, sebagaimana dinyatakan oleh Tiara Anisya Windya Elyana bahwa dalam keluarganya sudah melaksanakan fungsi ini, fungsi keluarga dalam hal tersebut adalah bisa mengajarkan anak untuk mempunyai sikap menghargai hasil 
karya atau kreativitas orang lain walaupun kreativitas tersebut kurang menarik. Menurut keluarganya, seseorang tidak boleh semena-mena mencelanya, tetapi harus tetap menghargai walaupun kreativitas tersebut merupakan sesuatu hal yang biasa saja. Dalam suatu kelompok misalnya, inisiatif kelompok antar individu biasanya memiliki masalah dalam hal perbedaan. Hal itu dalam keluarga, misalnya orang tua harus bisa mengajari anak untuk bisa menerima suatu perbedaan pendapat dari orang lain, tidak ingin menang sendiri dan inisiatifnya tidak harus selalu yang diterima. Oleh karena itu, menurutnya orang tua harus bisa mengajari anakanaknya dengan melakukan musyawarah untuk mencapai mufakat dengan menerima segala perbedan yang ada.

Ketujuh, tempat berekreasi dan mencurahkan isi hati (curhat). Menurut Khasin Ma'ruf, di saat anak jenuh atau stres dengan kegiatannya seperti belajar, keluarga merupakan tempat rekreasi yang pertama dan utama karena keluarga mampu memberi rasa nyaman, menghilangkan stres dan tekanan dalam diri anak. Dan bila anak mendapat masalah, kesulitan, hambatan ataupun tantangan keluarga adalah tempat curhat yang paling tepat untuk seorang anak karena anak telah memiliki ikatan psikologi dengan keluarganya.

Fungsi ketujuh ini sudah sangat terealisasikan dalam keluarga Ninda Septa Zulfanita, karena bagi dia keluarga adalah bagian dari hidupnya.Dengan adanya keluarga dia bisa mencurahkan berbagai keluhan yang dia alami,baik mengenai pelajaran, teman, dan masalah lainnya. Kalau keluarganya mempunyai waktu luang atau pada saat liburan, biasanya mereka pergi berekreasi, tidak harus pergi ketempat wisata. Menurut dia, makan bersama diluar juga sudah termasuk berekreasi.

Memperkuat penilaian Ninda tersebut, Maharani Silvia Malikhah menyatakan bahwa keluarga memang bisa dijadikan tempat berekreasi dan curhat, namun kenyataan dalam masyarakat masih banyak anak-anak yang cenderung menutup diri dari keluarganya. Mereka memilih untuk tidak menceritakan semua yang sedang dialami atau dirasakannya, justru mereka cenderung memilih bercerita kepada teman-teman mereka. Mereka memilih hal-hal yang akan diceritakan kepada keluarga mereka, tidak semua diceritakannya 
Adapun realisasi fungsi keluarga dalam pendidikan anak menurut Al-Quran surat Luqman ayat 13-19 dapat dideskripsikan sebagai berikut. Pertama, menanamkan iman dan tauhid. Keluarga adalah tempat belajar pertama sebelum sekolah, pendidikan agama terutama tauhid harus selalu ditanamkan pada diri anak melalui keluarga (Muhammad Lutfil Hakim). Menurut Yunita Sari, fungsi keluarga yang pertama berdasarkan Q.S. Luqman ayat 13-19 adalah untuk menanamkan iman dan tauhid kepada anak adalah benar adanya. Seorang anak yang tumbuh harus diberikan ajaran paling mendasar dan paling penting, ajaran yang dapat dijadikan pondasi serta bekal dalam menjalani kehidupannya. Ajaran tersebut adalah tentang keimanan dan tauhid. Bagi umat Islam, keimanan adalah inti dari semuanya. Dalam diri anak perlu ditanamkan keimanan dan keluarga adalah sebagai subjek pendidik yang tepat, karena keluarga adalah orang-orang yang dijadikan panutan oleh anak yang didik dan akan mudah bagi seorang anak itu menerima ajaran dari orang paling terdekat yaitu keluarganya.

Tidak jauh berbeda dengan Yunita, Maharani Silvia Malikhah menyatakan bahwa keluarga harus menanamkan iman dan tauhid kepada anak sejak usia dini karena iman dan tauhid merupakan hal yang paling utama sebagai pedoman untuk melakukan apapun di dunia ini. Jika iman dan tauhid sudah tertanam baik pada diri anak maka anak pasti tidak akan menyimpang dari norma-norma agama maupun sosial. Di dalam masyarakat sekitar tempat tinggalnya, menurutnya fungsi ini sudah dilaksanakan dengan baik. Fungsi pertama ini sudah diterapkan dalam keluarga Ninda Septa Zulfanita, dimana keluarganya telah mengajarkan untuk mempercayai dan taat kepada Allah subhanahu wata'ala dengan beribadah seperti shalat,mengaji,bersedekah,dan mengerjakan kebaikan serta selalu bersyukur atas apa yang telah Allah berikan..

Hal yang sama juga dirasakan oleh Maulida Swastuti, yakni kedua orang tuanya telah menanamkan iman dan tauhid kepadanya sejak masih kanak-kanak, orang tuanya adalah mengajak dan mengajarinya untuk sholat sejak dini dan memasukkannya ke Taman Pendidikan al-Quran (TPQ) sebelum dia masuk taman kanak-kanak, sehingga, ilmu agama dia dapatkan lebih awal dibanding ilmu umum dan membuat hal tersebut tertanam kuat dalam hati dan dirinya. 
Kedua, menumbuhkan sikap hormat dan bakti pada orangtua. Keluarga harus mengajarkan untuk menumbuhkan sikap hormat dan bakti kepada orang tua sebab muslim yang baik tentu memiliki kewajiban untuk berbakti kepada orang tua, baik ibu maupun ayah. Fungsi ini sudah diterapkan dalam keluarga Ninda Septa Zulfanita, orangtuanya mengajarkan untuk tidak membantah,tidak durhaka,tidak berkata kasar, dan selalu mendoakan mereka untuk keselamatan di dunia maupun di akhirat nanti karena mereka sudah merawat dan membesarkan dia dengan penuh kasih sayang, dan keikhlasan. Hal yang sama juga dinyatakan oleh Nor Muhammad Husein, bahwa keluarganya telah mengajarkan sikap hormat dan berbakti sejak dini. Dia dan saudara-saudaranya telah diajari unggah-unggub dalam masyarakat Jawa yang sangat berguna pada fungsi ini.

Mendukung pernyataan di atas, Alfi Lutfiana menyatakan bahwa orang tua memang harus mulai mengajarkan kepada anak bahwa yang lebih muda harus menghormati yang tua, agar ketika beranjak dewasa anak akan mempunyai etika yang baik, dengan cara orang tua memberikan contoh kepada anaknya melalui bagaiman etika orang tuannya kepada neneknya.Terkait dengan hal ini, Annisa Cahyalinamengakui bahwa dengan cara yang berbeda kedua orang tuanya mengajarkan apa arti hormat dan berbakti dengan orang tua dengan baik. Jika pelaksanaan fungsi ini dilakukan dengan cara yang sama dengan orang pada zaman dahulu sebelum dikenal adanya kehidupan modern itu, tentu kurang relevan. Oleh karena anakanak pada generasi saat ini telah terkontaminasi dengan sesuatu yang serba modern dan kebarat-baratan, padahal tidak semua hal yang modern itu positif. Dengan memfilter terhadap hal-hal modern yang negatif diharapkan sikap hormat dan bakti pada orang tua masih dilakukan dengan baik.

Keempat, mendorong anak taat beribadah, terutama salat. Ibadah merupakan pondasi ketentraman daalam keluarga terutama dalam ibadah sholat, orang tua mempunyai tugas yang sangat penting untuk mengajarkan kepada anak-anaknya tentang sholat. Sejak dini anak sudah harus mulai dijari sholat, dan ketika anak tidak menunaikan sholat, orang tua harus menghukum anak, dan yang lebih penting lagi, orangtua harus memberikan contoh agar anak 
mengikutinya (Alfi Lutfiana). Mendorong anak untuk taat beribadah shalat itu merupakan salah satu kunci sukses fungsi keluarga. Karena shalat adalah tiangnya agama Islam, maka orangtua selayaknya selalu mengajari anak tentang praktik shalat dan apa saja manfaat yang diperoleh ketika shalat, hal tersebut secara tidak langsung akan menumbuhkan kecintaan anak kepada Allah (Tri Apriliyani Saputri). Menurut Rizqi Aqidatul Izza, beribadah kepada Allah merupakan kewajiban bagi setiap muslim terutama ibadah shalat. Keluarga berperan penting dalam menjadikan anak taat beribadah, agar anak tambah rajin ibadah, keluarga bisa menyekolahkan anak di lembaga pendidikan yang berbasis agama, karena hal tersebut dapat mempengaruhi ketekunan anak karena sudah terbiasa belajar beribadah.Kemudian kelurga juga dapat memperkenalkan anak pada lingkungan tempat peribadahan, hal itu bertujuan agar anak dapat memperoleh ilmu beragama dari pusatnya dan agar dapat timbul rasa cinta pada agamanya.Realisasi fungsi keempat ini dilaksanakan dengan baik dalam keluarga Maulida Swastuti sebagaimana pengakuannya, bahwa sejak masih kanak-kanak, orang tuanya senantiasa mengajaknya untuk ikut salat bersama mereka meskipun ia belum dapat menjalankan salat dengan sempurna. Ketika ia memasuki usia baligh, orang tuanya tidak pernah lelah mengingatkannya untuk melaksanakan salat wajib lima waktu

Kelima, menanamkan cinta kebenaran ( $m a^{\prime} r u f$ ) dan menjauhi yang buruk (munkar). Tolong menolong dalam hal kebaikan dan saling mengingatkan dalam menjauhi kejelekan merupakan realisasi dari amar ma'ruf nabi munkar. Allah Maha Memaafkan segala kesalahan jika hamba-Nya bertaubat dengan taubatan nasuba dan Allah akan memberkan petunjuk kepada hamba-Nya yang berbuat kebaikan (Umi Rofiatul Masfufah). Terkait dengan hal ini, Siti Qoniah menyatakan bahwa dengan norma-norma keluarga yang benar yang ditanamkan sejak kecil maka anak akan tahu mana yang baik dan yang buruk dan mampu melaksanakannya.

Realisasi dari fungsi ini tampak dalam pernyataan Yunita Sari, bahwa dalam masyarakat di sekitarnya hal tersebut sangat jelas terlihat, dimana masyarakat berkomitmen untuk menanamkan kebenaran dalam diri anak-anak dan menjauhi keburukan. Fungsi ini sangat nyata dan penting dalam pengajaran kepada anak-anak, 
ia yakin semua orang tua tidak akan membiarkan anak-anaknya melakukan keburukan, pastilah orang tua mengharapkan yang terbaik untuk anak-anaknya.

Selanjutnya menurut Fuji Astuti, selain dalam Q.S. Lukman yang menyebutkan tentang cinta kebenaran ( $m a{ }^{\prime} r u f$ ) dan menjauhi yang buruk ( munkar), Allah juga berfirman dalam Q.S. Ali Imran ayat 110 yang artinya : Kamu adalah umat yang terbaik yang dilabirkan untuk manusia, menyurub kepada yang ma'ruf dan mencegah yang munkar, dan beriman kepada Allah......" Lebih lanjut Fuji menyatakan, "Insya Allah, orang tua kami selalu menanamkan dan memberikan keteladan sikap seperti itu, serta kakak saya membimbing adiknya untuk menjadi orang yang baik dimanapun kami berada." Demikian pula Hilyatul Ulya menyatakan, "Orang tua saya selau menjelaskan apa itu yang buruk dan apa itu yang baik, apa yang harus dipatuhi dan apa yang harus ditinggalkan, larangan-larangan Allah yang harus ditinggalkan dan perintah Allah yang harus dipatuhi."

Keenam, menanamkan jiwa sabar dalam menghadapi cobaan. Sabar dalam menghadapi cobaan merupakan akhlak terpuji. Maka keluarga perlu menanamkan sifat sabar pada anak karena dengan sabar niscaya manusiaakan senantiasa dekat dengan Allah SWT. Allah akan selalu berasma dengan orang-orang yang sabar. Saat cobaan melanda seseorang sebaiknya ia menanamkan sifat sabar karena sesungguhnya orang-orang yang sabar akan mendapat pahalanya (Rizqi Aqidatul Izza). Menurut Yunita Sari, anak-anak yang tumbuh di lingkungan sekitar harus dididik oleh orang tuanya untuk selalu bersabar dalam menghadapi cobaan.

Sikap sabar itu bukan hanya diam dan terbertopang dagu, melainkan suatu tekad yang disertai usaha keras untuk mendapatkannya serta bertawakal ketika tidak berhasil, Fungsi itu sudah terealisasikan dalam keluarga Ninda Septa Zulfanita, seperti sabar saat mendapat musibah,sabar dalam mencari ilmu,sabar saat ada tetangga yang membicarakan hal-hal yang buruk tentang keluarganya, saat sakit ataupun sabar saat dalam perjalanan karena biasanya banyak sekali orang-orang yang tidak mempunyai kesabaran dan malah membuat mereka menjadi celaka. Ajaran 
kesabaran juga telah direalisasikan dalam keluarga Anisha Nur Fatihah, dia menyatakan bahwa ketika kelas 4 SD, rumahnya ditabrak oleh sebuah truk yang sangat besar. Sebagian dari bangunan rumah hancur dan barang-barang lainnya pun tidak bisa berfungsi lagi. Menurut dia itulah cobaan terberat, lalu kedua orangtuanya berkata "Sabar, pasti ada hikmah di balik semua ini, Allah selalu punya rencana yang baik untuk umat-Nya". Sejak saat itu dia menjadi sabar ketika mendapat cobaan yang berat. Dengan sabar seseorang akan tahu bahwa hidup itu tidak instan, selalu ada proses-proses perubahan di dalamnya.

Ketujuh, menumbuhkan sikap rendah hati, tidak angkuh dan sombong dalam pergaulan. Keluarga berperan penting dalam mengajarkan anak untuk menumbuhkan sikap rendah hati, tidak angkuh dan sombong dalam berteman. Dalam hal ini Allah berfirman yang artinya, " ... dan janganlah kamu memalingkan mukamu dari manusia (karena sombong) dan janganlah kamu berjalan di muka bumi dengan angkuh. Sesungguhnya Allah tidak menyukai orangorang yang sombong lagi membanggakan diri (Q.S. Luqman:18). Maka dari itu keluarga perlu mengajari anak untuk tidak memilihmilih dalam berteman, menyadarkan kepada anak bahwa manusia itu berasal dari Allah dan akan kembali kepada-Nya, semua yang dimiliki didunia ini hanya titipan dari Allah, seharusnya kita sadar untuk apa kita bersikap angkuh dan sombong bila semua akan kembali kepada-Nya. Mengajarkan anak untuk bersikap rendah hati, tidak angkuh dan tidak sombong akan mengangkat derajat seseorang dan mengajari anak untuk berlomba-lomba untuk menjadi pribadi yang rendah hati dalam hidup ini agar lebih berarti (Rizqi Aqidatul Izza).

Fungsi ini telah diterapkan dalam keluarga Utami Dwi Ningrum, tetapi dalam keluarga-keluarga lain masih perlu untuk ditingkatkan. Sikap ini menurutnya sangatlah penting untuk ditanamkan dan diterapkan,semua yang dimiliki seseorang di dunia ini semata-mata hanya titipan dari Allah.

Kedelapan, menanamkan pola hidup sederhana. Menurut Rizqi Aqidatul Izza, Islam mengajarkan agar manusia hidup sederhana. Dengan hidup sederhana, manusia selalu akan merasa 
cukup, bahagia, dan bersyukur pada Allah. Sebaliknya Allah melarang manusia untuk hidup mewah dan boros. Keluarga dapat mengajari anak untuk bersikap hidup sederhana dengan berhemat dan menabung. Berhemat bukan berarti mendidik anak bersikap pelit terhadap dirinya sendiri maupun orang lain. Maksudnya disini adalah menggunakan sesuatu sesuai kebutuhan tidak menggunakan secara berlebihan. Melatih anak menanbung, mengajarkan untuk membedakan antara keinginan dan kebutuhan, mendidik anak bersikap sederhana dalam keluarga dimulai dari kemampuan memahami membedakan antara keinginan dan kebutuhan, mana yang dirasakan sebagai kebutuhan dan mana yang hanya bersifat keinginan. Kehidupan keluarga mencerminkan hidup seseorang, anak yang berada di keluarga sederhana juga akan bersikap sederhana, namun anak yang berada di keluarga menengah ke atas juga tidak selayaknya bersikap sombong (Muhammad Lutfil Khakim).

\section{Kesimpulan}

Realisasi fungsi keluarga secara umum dalam pendidikan anak menurut mahasiswa IAIN Salatiga, yang meliputi (a) tempat mendapatkan sesuatu yang berguna untuk mempertahankan kehidupannya, pencegahan bahaya dari luar, latihan bekerjasama untuk persiapan bermasyarakat; (b) tempat mengadakan ikatanikatan psikologik dengan seluruh anggota keluarga; (c) tempat membentuk identitas personal yang terkait dengan identitas keluarga; (d) tempat mempelajari pola-pola peran individu yang sesuai dengan peran jenis kelaminnya; (e) tempat belajar berintegrasi dengan masyarakat dan menerima pola-pola kehidupan masyarakat; (f) tempat belajar untuk menghargai kreativitas dan inisiatif dari individu lain; dan (g) tempat berekreasi dan mencurahkan isi hati (curhat), telah berlangsung dengan cukup baik, sejauh yang terkait dengan internal keluarga mahasiswa yang menjadi responden dalam penelitian ini. Namun, ketika menyangkut masyarakat sekitar di luar keluarga mahasiswa, masih belum semua keluarga merealisasikan fungsinya dengan baik. 
Realisasi fungsi keluarga dalam perspektif Al-Quran surat Luqman ayat 13 s.d. 19 dalam pendidikan anak menurut mahasiswa IAIN Salatiga meliputi (a) tempat menanamkan iman dan tauhid; (b) tempat menumbuhkan sikap hormat dan bakti pada orang tua; (c) menumbuhkan semangat kerja dengan penuh kejujuran; (d) tempat mendorong anak taat beribadah, terutama shalat; (e) tempat menanamkan cinta kebenaran ( $m a^{\prime} r u f$ ) dan menjauhi yang buruk (munkar); (f) tempat menanamkan jiwa sabar dalam menghadapi cobaan; (g) tempat menumbuhkan sikap rendah hati, tidak angkuh dan sombong dalam pergaulan; dan (h) tempat menanamkan sikap hidup sederhana, telah berlangsung lebih baik jika dibandingkan dengan kesimpulan nomor satu, juga sejauh yang terkait dengan internal keluarga mahasiswa yang menjadi responden dalam penelitian ini.

\section{Daftar Pustaka}

Achmadi. 1993. Islam sebagai Paradigma Ilmu Pendidikan. Yogyakarta: Aditya Media.

Amin, Ahmad. Tt. Etikai Ilmu Akhlak. Jakarta: PT. Bulan Bintang

Aminuddin. 1995. Stilistika Pengantar Memahami Bahasa dalam Karya Sastra.Semarang: IKIP Press.

Departemen Agama RI, Direktorat Jenderal Pendidikan Islam. 2006. Undang-Undang dan Peraturan Pemerintah RI tentang Pendidikan.

Departemen Agama RI. 2000. Al Qur'an dan Terjemahnya. Semarang:Asy-Syifa'.

Djamarah, Saiful Bahri. 2004. Pola Komunikasi Orang Tua dan Anak dalam Keluarga. Jakarta: PT Rineka.

Fajri, Em Zul dan Ratu Aprilia. t.t. Kamus Lengkap Bahasa Indonesia. t.kt: Difa Publiser.

Indar, Djumberansyah. 1994. Filsafat Pendidikan. Surabaya: Karya Abditama. 
Langgulung, Hasan. 2004. Manusia dan Pendidikan. Jakarta: Pustaka Alhusna Baru.

Muhadjir, Noeng. 1993. Ilmu Pendidikan dan Perubahan Sosial Suatu Teori Pendidikan. Yogyakarta: Rake Sarasin.

Mujib, Abdul dan Jusuf Mudzakir. 2006. Ilmu Pendidikan Islam. Jakarta: Kencana Prenada Media

Richey, Robert W. 1968. Planning for Teaching on Introduction. New York: Mc. Graw Hill Book Coy.

Shochib, Moh. 1998. Pola Asuh Orang Tua. Jakarta: PT. Rineka Cipta.

Sutopo, H.B. 2002. Metodologi Penelitian Kualitatif Dasar Teori dan Terapannya dalam Penelitian. Surakarta: Sebelas Maret University Press.

Tilaar, H.A.R. 2000. Pendidikan, Kebudayaan, Masyarakat Madani Indonesia. Bandung: Remaja Rosdakarya.

Tim Dosen IKIP Malang. 1981. Pengantar Dasar-Dasar Kependidikan. Surabaya: Usaha Nasional.

Ya'qub, Syikh 'Abdurrahman. 2005. Pesona Akhlak Rasulullah Saw., Terj. Zainal Muttaqin. Bandung: Mizan Pustaka. 